\title{
Analysis of economic value and livestock farming model based on the integration of cattle-palm oil plantation on peatlands in Pasangkayu regency, West Sulawesi, Indonesia
}

\author{
Nazlah K ${ }^{1)}$, Aminudin Afandhi' ${ }^{2)}$, Abdul Haris ${ }^{2)}$, S. Suyadi*3) \\ ${ }^{1)}$ Department of Agriculture, Pasangkayu Regency, West Sulawesi, Indonesia, Doctorate \\ Student of Environmental Science \\ 2) Postgraduate School, University of Brawijaya \\ ${ }^{3)}$ Faculty of Animal Science, University of Brawijaya, Veteran Street 65145 Malang, East \\ Java, Indonesia
}

Submitted: 14 December 2019, Accepted: 21 March 2020

\begin{abstract}
Pasangkayu Regency is one of the regencies in West Sulawesi that has the potential to apply the concept of sustainable agriculture through palm oil plantations. One of the efforts in developing sustainable farming systems is by integrating agriculture and livestock farming. The purpose of this study is to analyze the economic value and livestock model based on the integration of palm and cattle on peatlands in the Pasangkayu Regency. The study was conducted in palm oil plantations on peatlands in Pedongga District, Pasangkayu Regency, from June to August 2018. Data collection was carried out by interviewing and distributing questionnaires directly to 45 informants. The analysis was performed, including economic analysis, analysis of sustainability data, analysis of Multiple Goal Programming (MGP), also the drafting of the index, and the status of sustainability of integrated palm-cattle. The economic value of the farmers in integrated farming systems of cattle-palm on peatlands in the Pasangkayu Regency showed by the income earned was Rp. $11,069,436.18$ / year and much higher than the economic value without integration, which the income was only Rp. 916,982.73 / year. The integration-based livestock farming model observed from the ecological, economic, social, and cultural, and the legal and institutional dimensions were categorized as sustainable, while the infrastructure and technology dimensions were still below sustainable values. Therefore, the overall integration of palm and cattle on peatlands in the Pasangkayu Regency was categorized as sustainable.
\end{abstract}

Keywords: analysis of economic value; integration of palm-oil; pasangkayu regency; sustainable agriculture systems

\footnotetext{
*Corresponding Author: suyadi@ub.ac.id
} 


\section{INTRODUCTION}

Improving the farming system requires alternative technology as an effort to improve land productivity and increase farmers' incomes. The effort was carried out through the livestock business system technology that applies the concept of sustainable farming systems. The livestock development approach can be directed at developing integrated farming systems. Cattle as a livestock commodity is one of the meat-producing resources with high economic value, as well as other products such as leather, bones, and manure. Cattle integrated with plants can utilize byproducts of plants (crop residues) for animal feed. On the other hand, cattle can provide raw materials for organic fertilizer as a source of nutrients required for the plants.

Pasangkayu Regency is one of the regencies in West Sulawesi that has an area of 13,679 ha of palm oil plantations that have not yet produced, 28,417 ha of which is productive, and 709 ha that is not productive. Palm plantation waste can be used as food for cattle. These wastes include palm oil fronds, palm oil fruit juice, palm oil empty fruit bunches, palm kernel cake, and palm oil sludge. Not all palm oil waste can be used for animal feed directly, but it must go through physical, chemical, biological, or combination processing. Palm oil industry by-products (IKS) have enormous biomass as a source of cattle feed. IKS byproducts that are used as a food source have been extensively studied in Malaysia since 1986 (Zahari et al., 2003). The Agricultural Research and Development Agency has researched palm oil and cattle waste. The results concluded that the integration of palm oil could increase the productivity of palm oil, improve the plantation land ecosystem, and increase beef supply (Mathius, 2008). The purpose of this study is to analyze the economic value and livestock model based on the integration of oil-palm and cattle on peatlands in the Pasangkayu Regency.

\section{MATERIALS AND METHOD Area Study and Data Collection}

This research was conducted in peatland palm oil plantations in Pedongga District, Pasangkayu Regency, from June to August 2018. Data collection techniques were carried out using incidental techniques by interviewing and distributing questionnaires directly to 45 respondents (Sugiyono, 2012). Selected resource persons are integrated or unintegrated palm landowners with cattle in the research location.

\section{Economic Analysis}

An economic analysis of the costs and income of the integrated and unintegrated peatland palm oil processing system was obtained by recording all costs of palm oil and cattle production for one year. Palm oil production cost data needed are the costs of problem identification and analysis, pruning, herbicide, fertilizer, labor, and harvest costs. In contrast, the costs for cattle are the purchase of seeds and the cost of raising cattle. Revenue was calculated with the price of the product multiplied by the number of products. The calculation of the income of palm oil farmers who do integration or not integrated with cattle are:

\section{Income}

Income, according to Sudarsono (1995), is the result of revenue reduced by total costs, with the following formula:

$$
\mathbf{I}=\mathbf{T R}-\mathbf{T C}
$$

where:

$\mathrm{I}=$ Income (Rp),

$\mathrm{TR}=$ Total Revenue $(\mathrm{Rp})$

$\mathrm{TC}=$ Total Cost $(\mathrm{Rp})$

\section{R/C Ratio}

According to Sudarsono (1995), efficiency is defined as an effort to allocate inputs to get maximum production. The efficiency level of farming can be assessed from the results of a comparison between the output value and the input value. Efficiency in economic analysis acts as a measuring tool to measure or find out the 
benefits of the business. The formula for calculating efficiency is as follows:

$$
R / C \text { ratio }=T R / T C
$$

where:

$\mathrm{R} / \mathrm{C}$ ratio $=$ Comparison between revenues and costs

TR = Total Revenue (Rupiah. Year-1)

$\mathrm{TC}=$ Total Cost (Rupiah. Year-1)

\section{Analysis of Sustainability Data}

The analytical method used was the RAP Palm-Beef Cattle (Rapid Appraisal for Palm-Beef Cattle Pasangkayu) ordination technique. This method is a statistical technique by the multidimensional transformation of the Local Economic Development and Weight Determination Program for PEL Aspects. Analysis of the sustainability of the integrated management of palm oil and cattle was carried out with the MultiDimensional Scaling (MDS) approach, which is the development of the $\mathrm{SBH}$ RALED method used to assess the sustainability status of the integrated palm oil and cattle. The RALED program is a modified program from the RAPFISH (Rapid Assessment Techniques for Fisheries) program developed by the Fisheries Center, University of British Columbia, Canada.

The stages of this analysis are carried out through determining the attributes of the sustainability of the integration of palm oil and cattle, which cover five dimensions, namely ecology, economy, society and culture, infrastructure and technology, and law and institutions.

\section{Drafting of Index and Sustainability Status of Palm-Cattle Integration}

The score results of each attribute were analyzed with Multi-Dimensional Scaling (MDS) to determine the point that reflects the position of sustainability towards the two reference points, namely the good point and the bad point. The approximate score of each dimension was expressed on the worst scale (bad) 0 percent to the best (good) 100 percent. The score, which is the value of the sustainability index for each dimension, can be seen in the following Table 1 .

Table 1. Category of sustainability status for the integrated palm-cattle based on the index value of the RALED SBH analysis

\begin{tabular}{cc}
\hline Index Value & Category \\
\hline $0-25$ & Bad (Unsustainable) \\
$26-50$ & Less (Less Sustainable) \\
$51-74$ & Enough (Quite Sustainable) \\
$75-100$ & Good (Very Sustainable) \\
\hline
\end{tabular}

Multi-Dimensional Scaling (MDS) analysis, in addition to determining the value of the sustainability index, also provides leverage analysis, which is to find out the attributes that are sensitive to the sustainability of palm-cattle integration and the value of Monte Carlo as a comparison of the sustainability index value of palmcattle integration. Each attribute on each dimension was given a score based on the scientific judgment of the respondents. Scores range from $0-2$ starting from bad 0 (zero) to good 2 (two). Based on the Multi-
Dimensional Scaling (MDS) method, the position of sustainable points can be visualized through the horizontal axis and vertical axis.

The point rotation process can be visualized with a continuous index score of 0 percent (bad) and 100 percent (good). If the system under study had a continuous index value greater than or equal to 50 percent, then the system was said to be sustainable. If the index value was less than 50 percent, the system was considered unsustainable (Figure 1). 


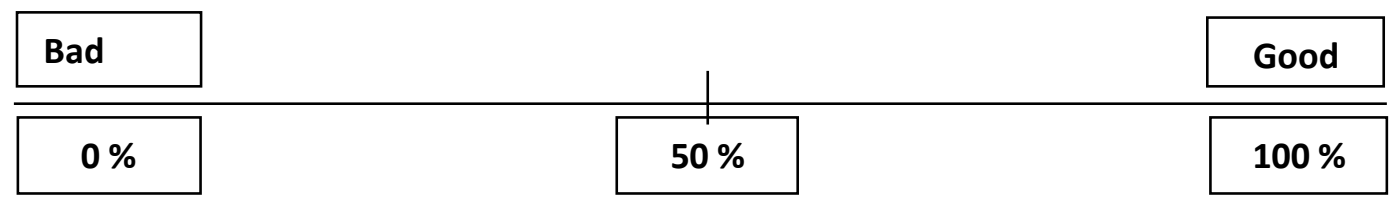

Figure 1. Illustration of the sustainability index for palm oil and cattle integration by 50 percent (sustainable).

\section{Multiple Goal Programming (MGP) Analysis}

MGP analysis was used to obtain optimization of the integration of oil-palm and cattle on peatlands in the Pasangkayu Regency. This concept makes it possible to include various objectives in producing optimization solutions. The mathematical equation used in this analysis consists of two functions, namely (1) the objective function equation and (2) the constraint function equation. The equation of the objective function mathematical model in the MGP model in this study which is an integrated palm oil plantation business with beef cattle was formulated as follows:

where:

$$
\mathrm{Z}_{\min }=\mathrm{P}_{1} \mathrm{~d}_{1^{-}}+\mathrm{P}_{2} \mathrm{~d}_{2}^{-}+\mathrm{P}_{3} \mathrm{~d}_{3}^{-}+\mathrm{P}_{4} \mathrm{~d}_{4}^{-}
$$

P1: maximizing peatland palm oil yields as the 1st priority goal

P2: maximizing the net income of palm oil farmers from peatland palm oil plantations as the $2^{\text {nd }}$ priority goal

P3: maximizing the net income of palm oil farmers who integrate with cattle on peatland palm oil plantations as the $3^{\text {rd }}$ priority goal

P4: maximizing the acquisition of animal feed from palm leaf and fronds waste from peatland palm oil plantations as the $4^{\text {th }}$ priority goal

\section{RESULTS AND DISCUSSION}

Economic Value in the Integration System of Cattle-Palm in Peatland Palm oil Plantations

The integrated system of oil palm plantation and cattle in the Pasangkayu Regency was carried out indirectly because the cow pen was located near the palm oil plantation area. Cattle feed was obtained from palm oil plantations, while waste from the pen was processed first before being turned into fertilizer for palm oil plantations. The income of palm oil farmers was distinguished based on income from the palm oil and cattle business. The results of the Bangun (2010) showed that farmers' income in Riau Province before integrating the cattle-palm was Rp. 14,872.18 / 8 months and after integrating the cattle-palm was Rp. 19,804,571 / 8 months or Rp. $2,475,571$ per breeder every month.
Based on the analysis results of the integration of palm and cattle on peatlands in the Pasangkayu Regency, the income earned was Rp. 11,069,436.18 / year, while the income of peatland palm oil farmers without integration was Rp. 916,982.73 / year. The low income of palm oil farmers in the study location was caused by the very low price of FFB; hence the farmers suffered losses. The results of interviews and data analysis showed that 12 farmers out of 45 respondents suffered losses. However, the integration of oil-palm and cattle can reduce the losses of farmers because of the income from raising livestock.

The results of research on the integration of oil-palm plantation and cattle on peatlands in Pasangkayu Regency, West Sulawesi Province, showed that the contribution of cattle to the income of palm 
oil farmers is Rp. 10,152,453.45 / year or Rp. 846,037.79 / month. Based on this, it can be concluded that the palm oil plantation business integrated with cattle has a very large contribution. According to Soehadji (1993), the amount of the contribution of the income to the farmer's household depends on the size and business objectives, where the livestock business, which is part-time household is less than $30 \%$, the business branch is $30 \%$ to $70 \%$. The main business or industrial business is $70 \%$ to $100 \%$.

Thus, it can be concluded that the cattle business was the main source of income in the integration of cattle-palm in Pasangkayu Regency. Based on observations at the location at the time of data collection, many palm oil farmers suffered losses due to high production costs. Meanwhile, palm oil sales were very low, ranging between Rp. 763.87 - Rp. $1,009.11 / \mathrm{kg}$ FFB. The integration of palm oil and cattle in peatland palm oil plantations has a significant effect on the profits/income of palm oil farmers.

The results of the business feasibility analysis based on the average $\mathrm{R} / \mathrm{C}$ ratio obtained by the integration of cattle-palm oil on peatlands was 1.55 , while the average $\mathrm{R} / \mathrm{C}$ ratio obtained by palm oil plantations without integration was 1.09. These results indicated that the integrated cattle-palm effort is feasible. Palm oil plantation has potential waste such as leaves, fronds, empty bunches, shells, fruit fibers, palm oil mud, and palm kernel cake, which can be used as animal feed.

This waste contains dry matter, crude protein, and crude fiber, which nutritional value can be utilized as ruminant animal feed ingredients (Nurhayu et al., 2013). Farmers who integrate their palm oil plantations with cattle can also utilize the waste in the form of palm oil fronds originating from their plantations as beef forage feed.

According to Jaelani et al. (2014), the production of palm oil fronds is estimated at 6.3 tons/ha/year, assuming 130 hectares are planted per hectare, and each tree produces 22 stems, and each trunk weighs $2.2 \mathrm{~kg}$. Based on the results of research on peatland palm oil farmers in Pasangkayu Regency, West Sulawesi Province, with a total of 136 trees per hectare, the production of palm oil fronds was 2,626.77 $\mathrm{kg}$ of dry material per hectare per year or $7,197 \mathrm{~kg}$ of dry material per hectare per day. If it is assumed that $2-4 \%$ dry matter needs are based on body weight (Arora, 1995) or an average of $3 \%$ of body weight with a bodyweight of $250 \mathrm{~kg}$, then palm leaves and fronds waste can fulfill the needs of 2-3 cattle/day.

The Cattle-Palm Integration Model in Peatland Palm oil Plantations Dimension of Ecology

The results of the analysis of the sustainability index of the ecological dimension based on beef cattle farms areas were $55.95 \%$ or with a quite sustainable category. The results of the sustainability index value of the ecological dimension can still be improved through sensitive attributes. Sensitive attributes influence the value of the ecological dimension of the sustainability index through leverage analysis. The results of the Leverage analysis of the ecological dimension had four attributes that are sensitive to the value of the ecological dimension of the sustainability index, including: (1) cleanliness of the pen; (2) level of land use for agriculture and livestock farming; (3) land (soil fertility) and (4) beef cattle maintenance systems. Sensitive attributes are 50 percent greater than the scale (> 3). 


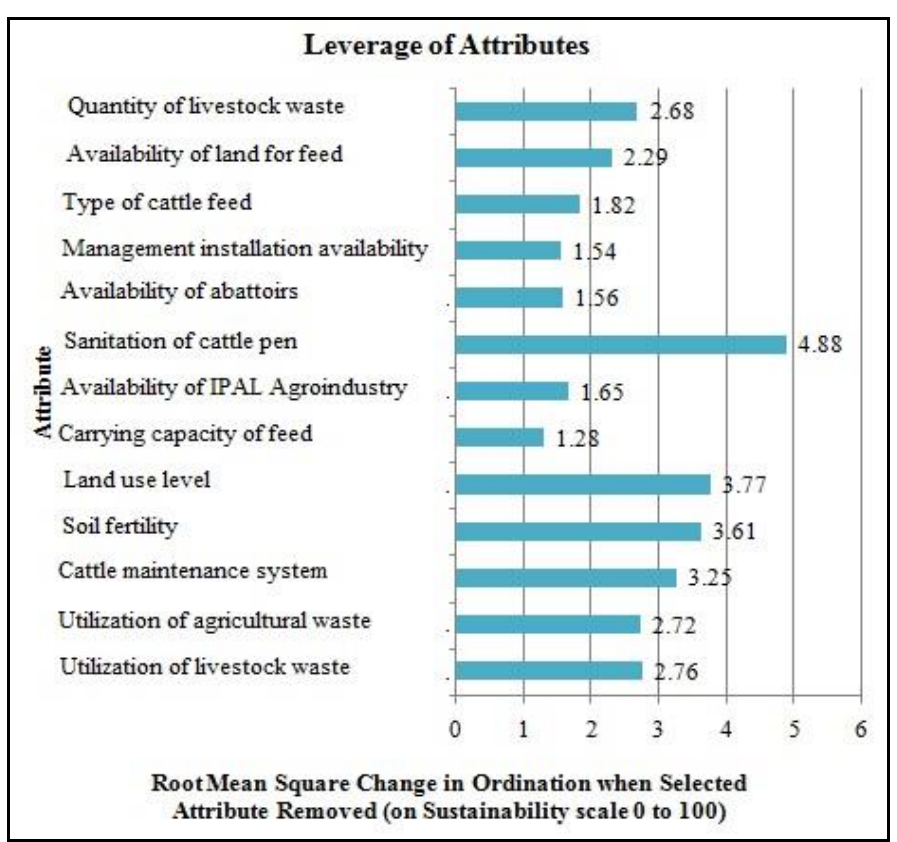

Figure 2. The value of each ecological dimension attribute.

\section{Economic Dimension}

The results of the analysis of the sustainability index of the economic dimensions of the beef cattle farms-based areas were $58.79 \%$ or with a quite sustainable category. Based on the Leverage analysis results, three attributes are sensitive to the value of the economic dimension of the sustainability index, including (1) availability of the feed industry; (2) the amount of livestock business subsidies; (3) changes in the Regional Government Budget value in the livestock sector (last five years).

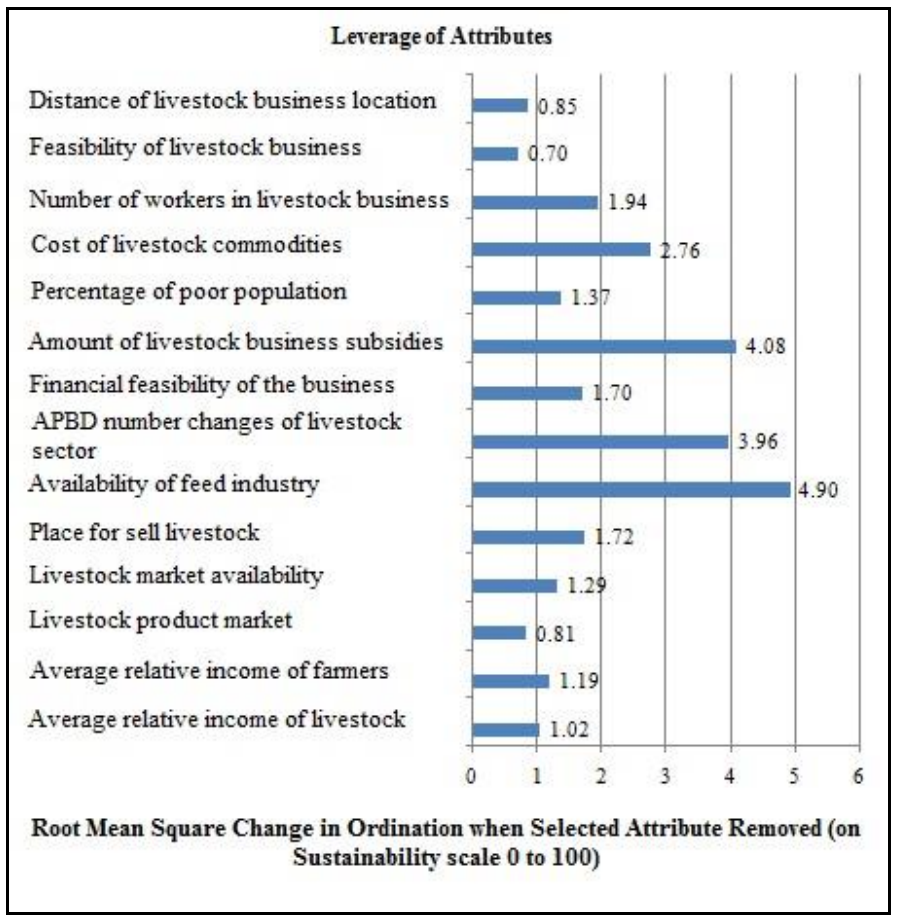

Figure 3. The value of each economic dimension attribute. 


\section{Social and Cultural Dimensions}

The results of the analysis of the sustainability index of the social and cultural dimensions for beef cattle farms-based areas were $54.10 \%$ or with a quite sustainable category. Based on the Leverage analysis results, five attributes are sensitive to the value of the social and cultural dimension of the sustainability index, including (1) frequency of counseling and training; (2) the rate of absorption of agricultural labor; (3) the frequency of conflicts related to livestock farming; (4) alternative business besides livestock agribusiness; (5) the level of employment of livestock agro-industry labor.

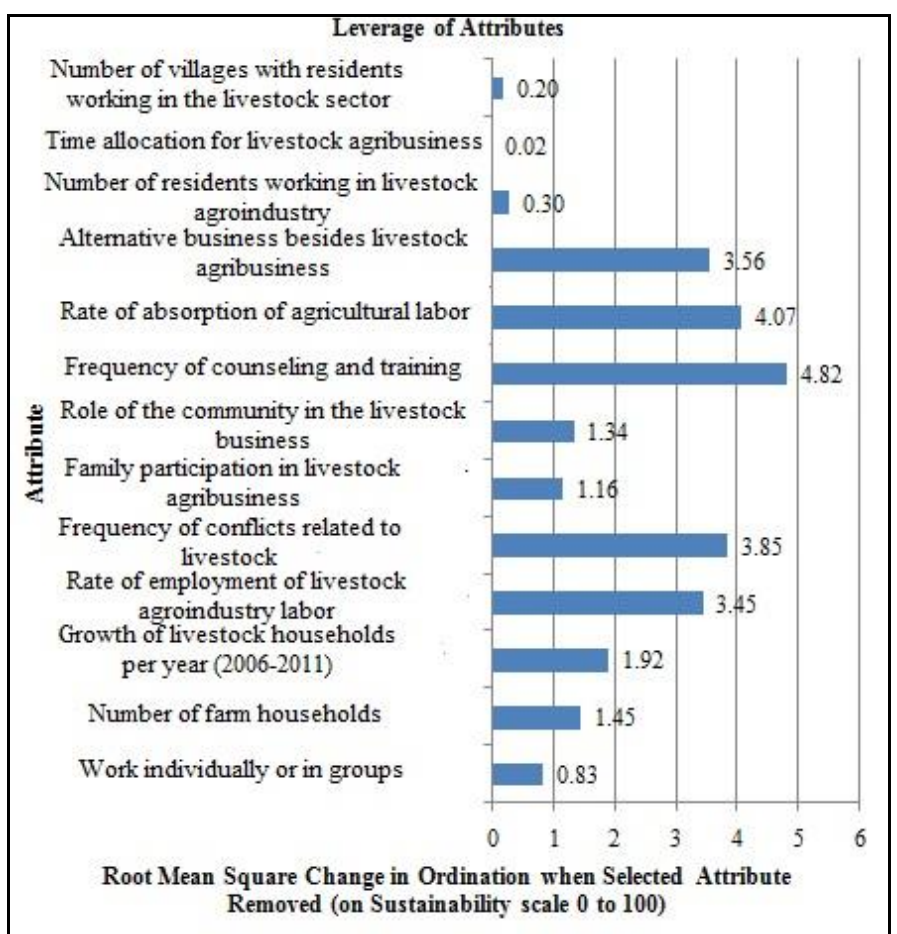

Figure 4. The value of each social and cultural dimension attribute.

$\begin{aligned} & \text { Dimensions of Technology and } \\ & \text { Infrastructure }\end{aligned}$
$\begin{aligned} & \text { dimensions of the sustainability index, } \\ & \text { including: (1) information and transportation }\end{aligned}$
the results of the analysis of the
technology; (2) availability of agribusiness
infrastructure dimensions for beef cattle
farming-based areas were $33.28 \%$ or less $\begin{aligned} & \text { for processing livestock products; (4) } \\ & \text { sustainable. Based on the Leverage analysis agro-industry waste treatment } \\ & \text { results, six attributes are sensitive to the } \\ & \text { value of the technological and infrastructure }\end{aligned}$




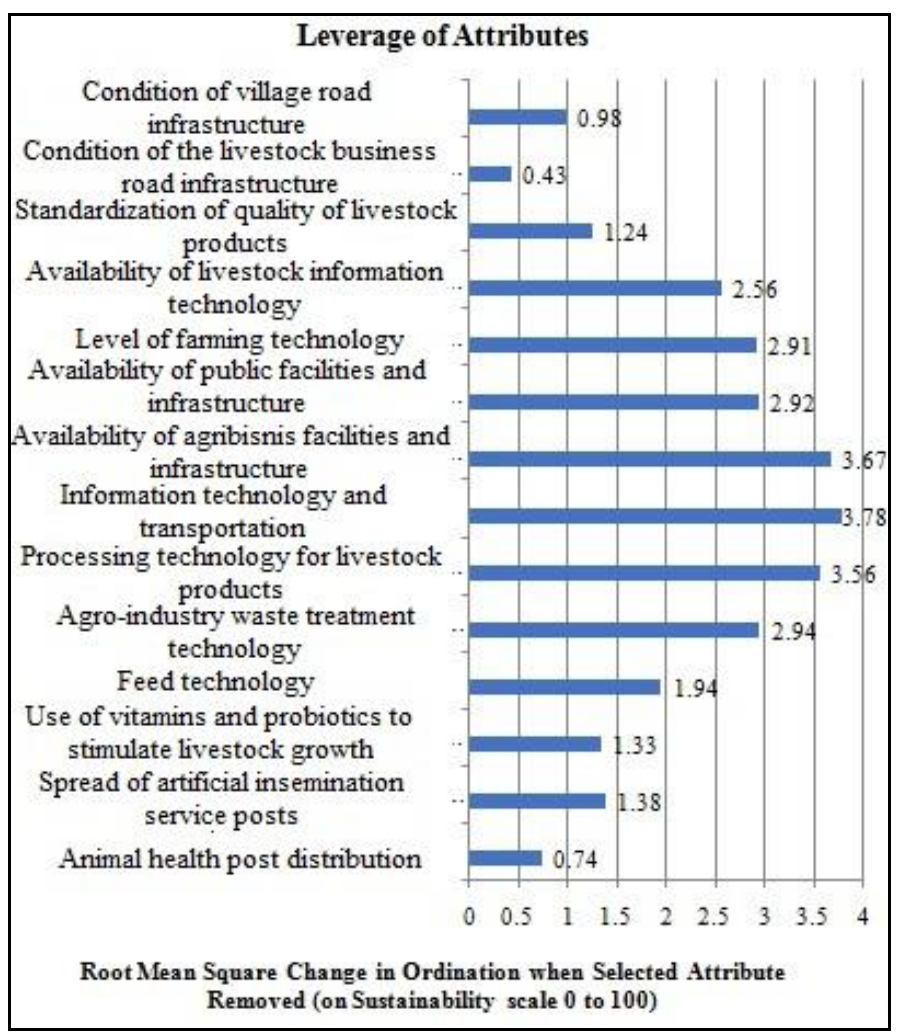

Figure 5. The value of each technological and infrastructure dimension attribute.

\section{Legal and Institutional Dimensions}

Based on the analysis results, the sustainability index of the legal and institutional dimensions for beef cattle farming-based areas were $53.87 \%$ or with an entirely sustainable category. Based on the Leverage analysis results, two attributes were sensitive to the value of the legal and institutional dimension of the sustainability index, including: (1) livestock farmer groups; (2) agricultural extension institutions.

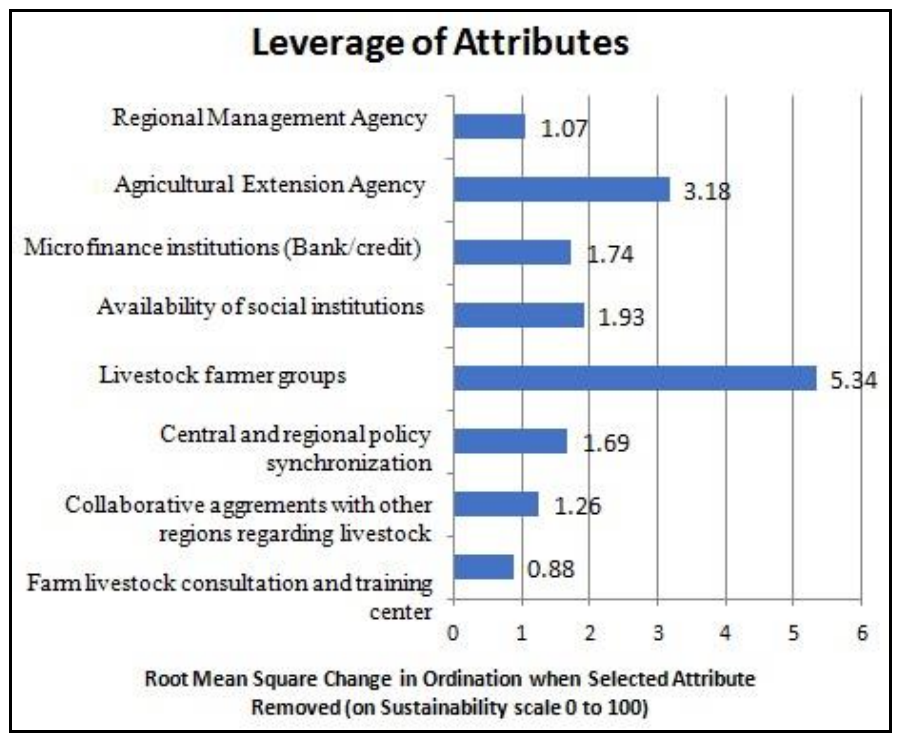

Figure 6. The value of each legal and institutional dimension attribute. 


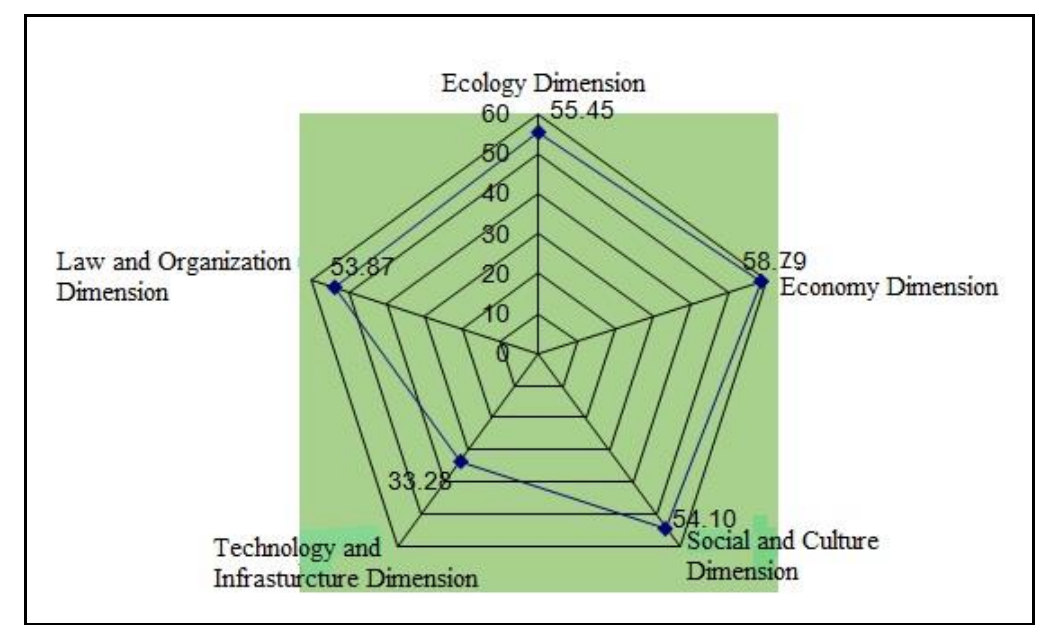

Figure 7. Kite diagram

Optimizing the Integration of Peat-Palm oil Peat

The optimal conditions using the MGP approach showed higher values than the real conditions (Table 2).

It means that farmers still have the opportunity to improve their farming to achieve optimal conditions by implementing the integration of palm oil according to optimal conditions. A comparison of the real conditions with the optimization conditions of peatland oilpalm integration efforts in the Pasangkayu Regency in one year can be seen in Table 2.

Table 2. The results of the optimization of the integration of palm and cattle peatlands in Pasangkayu Regency

\begin{tabular}{|c|c|c|c|c|}
\hline \multirow{2}{*}{ Obstacles } & \multicolumn{2}{|c|}{ Conditions } & \multicolumn{2}{|c|}{ Permissible conditions } \\
\hline & Real & Optimization & Increase & Reduction \\
\hline Goals & & & & \\
\hline $\begin{array}{l}\text { Palm Production } \\
\text { (ton/ha/year) }\end{array}$ & 11,97 & 16,00 & Infinity & 17,26 \\
\hline $\begin{array}{l}\text { Palm Income } \\
\text { (Rp/year) }\end{array}$ & $916.982,73$ & $3.500 .000,00$ & Infinity & $3.500 .000,00$ \\
\hline $\begin{array}{l}\text { Integration Revenue } \\
\text { (Rp/year) }\end{array}$ & $11.069 .436,18$ & $15.000 .000,00$ & Infinity & Infinity \\
\hline $\begin{array}{l}\text { Potential Waste } \\
\text { (Kg/ha/year) }\end{array}$ & $1.842,15$ & $6.000,00$ & Infinity & $4.777,97$ \\
\hline Functional & & & & \\
\hline Land Area (ha) & 1,426 & 2,00 & 2,59 & Infinity \\
\hline Venture & 9.613 .78 & 17.151 .4 & Infi & 17.151 .4 \\
\hline Capital (Rp/year) & 8,96 & 51,30 & nity & 52,00 \\
\hline
\end{tabular}

Average palm oil production in the real conditions of palm oil farming can still be increased to infinity and at least 17.26 tons/ha/year. It means that real palm oil farming is theoretically still not optimal. According to Lubis (2008), palm oil FFB production can reach 31 tons/ha/year. If palm oil handling is not carried out optimally based on MGP optimization analysis, it can reduce production to infinity. The average income of palm oil farmers who did not integrate with the real conditions was very low at Rp. 916,982.73 / year and can still be optimized to infinity, while the minimum income should be Rp. $3,500,000.00 /$ year (Table 2). The very low income from real palm oil farming is theoretically still not optimal. This was 
caused by the low price of FFB, which applies with a large capital cost that can reach Rp. 9,613,788.96 / year, so the farmers are only able to keep their palm oil plants to survive.

The income of farmers who are integrating cattle and palm on peatlands can provide hope. The average income of palm oil farmers who integrate with real conditions is Rp. 11,069,436.18 / year and can still be optimized to infinity. This condition can also reduce income to infinity (Table 2). Theoretically, income on the integration of cattle-palm in peatlands can be optimized by taking into account several things such as increasing land tenure and reducing fertilization costs by utilizing cow manure waste as an alternative to inorganic fertilizer. Wahyono and Hardianto in Sodiq and Machfudin (2012), recommend that the development of beef cattle business must be supported by local specific sources of raw materials and oriented to the integration of plants and livestock. Aside from being relatively inexpensive, the integration of crops and livestock can also improve the fertility of the land and estate crops, which will create sustainable agricultural businesses, as well as the welfare of farmers through increased income and efficiency of farming (Yamin et al., 2010).

The potential of palm leaves and fronds as feed sources showed that the average waste in the real condition is still low and can be optimized to infinity, with a permissible decline in conditions of 4.78 tons/ha/year (Table 2). Production of palm leaves and fronds based on real conditions can supply up to $47.66 \%$ of the land capacity to accommodate livestock units. This condition can still be optimized when considering several things, namely through improving the quality of waste by processing physical, chemical, and biological biotechnology. Based on Hidayat and Hidayat(2017), 125 palm trees per hectare will produce a production of palm oil fronds of 6.06 tons/ha/year or 16.6 $\mathrm{kg} / \mathrm{ha} /$ day.

\section{CONCLUSION}

The economic value of the farmers in integrated farming systems of cattle-palm on peatlands in the Pasangkayu Regency was higher than the economic value without integration. Likewise, the average $\mathrm{R} / \mathrm{C}$ ratio obtained by the integration of palm oil and cattle on peatlands was greater than palm oil plantations without integration.

The integration-based livestock farming model observed from the ecological, economic, social, and cultural, and the legal and institutional dimensions were categorized as sustainable, while the infrastructure and technology dimensions were still below sustainable values. However, the overall integration of palm and cattle on peatlands in the Pasangkayu Regency was categorized as sustainable. The integration of palm and cattle on peatlands in the Pasangkayu Regency in the real conditions was still lower than the optimal conditions. Optimization of palm oil can be carried out through the integration of palm oil and cattle on peatlands to reduce input and enlarge the output.

\section{REFERENCES}

Arora, S. (1995). Pencernaan Mikroba Pada Ruminansia (B. Srigandono (ed.); 2nd ed.). Gadjah Mada University Press.

Bangun, R. (2010). Pengembangan Sistem Integrasi Sapi-Kebun Kelapa sawit Dalam Peningkatan Petani di Provinsi Riau. Badan Penelitian Dan Pengembangan Provinsi Riau.

Hidayat, M., \& Hidayat, A. A. A. (2017). Analisis Kelayakan Usaha Integrasi Sapi Potong Dan Perkebunan Kelapa Sawit Di Desa Karang Taruna Kabupaten Tanah Laut, Kalimantan Selatan. Seminar Nasional Peternakan 3. Jaelani, A., Gunawan, A., \& Asriani, I. (2014). Pengaruh Lama Penyimpanan Silase Daun Kelapa Sawit terhadap Kadar Protein dan Serat Kasar. Universitas Islam Kalimantan. 
Lubis, A. U. (2008). Kelapa Sawit (Elaeis guineensis Jacq) di Indonesia (2nd ed.). Pusat Penelitian Kelapa Sawit.

Mathius, I. (2008). Pengembangan Sapi Potong Berbasis Industri Kelapa Sawi. Pengembangan Inovasi Pertanian.

Nurhayu, A., Ishak, A. B., \& Andi, E. (2013). Pelepah dan Daun Sawit sebagai Pakan Substitusi Hijauan pada Pakan Ternak Sapi Potong di Kabupaten Luwu Timur Sulawesi Selatan. Balai Pengkajian Teknologi Pertanian Sulawesi Selatan.

Soehadji. (1993). Kebijakan Pembangunan Peternakan Untuk Pengembangan Pedesaan. Lustrum VI Faterna Unand.
Sudarsono. (1995). Pengantar Ekonomi Mikro. LP3ES.

Sugiyono. (2012). Metode Penelitian Kuantitatif Kualitatif dan $R \& D$. Alfabeta.

Wan Zahari, M., Abu Hassan, O., Wong, H. K., \& Liang, J. B. (2003). Utilization of oil palm frond - based diets for beef and dairy production in Malaysia. Asian-Australasian Journal of Animal Sciences, 16(4), 625-634. https://doi.org/10.5713/ajas.2003.625

Yamin, M., Muhakka, \& Abrar, A. (2010). Kelayakan sistem integrasi sapi dengan perkebunan kelapa sawit di Propinsi Sumatera Selatan. Jurnal Pembangunan Manusia, 10(1). 